\author{
(online) $=$ ISSN $2285-3642$ \\ ISSN-L = 2285 - 3642 \\ Journal of Economic Development, Environment and People \\ Volume 3, Issue 2, 2014 \\ URL: $\underline{\text { http://jedep.spiruharet.ro }}$ \\ e-mail: office jedep@spiruharet.ro
}

\title{
Social Innovation Role in Creating a Methodological Framework Adapted to Reality
}

\author{
Mariem Kchaich Ep Chedli ${ }^{1}$, Teodora Bianca Floricel ${ }^{2}$, Larisa Mihoreanu ${ }^{3}$ \\ ${ }^{1} \mathrm{PhD}$ student, Bucharest University of Economic Studies, Romania, mariemkchaiech@gmail.com \\ ${ }^{2} \mathrm{PhD}$ student, The Bucharest University of Economic Studies, Romania, teo89 teo@yahoo.com \\ ${ }^{3} \mathrm{PhD}$ student, Larisa Mihoreanu Bucharest University of Economic Studies, Romania, \\ Imihoreanu@yahoo.com
}

\begin{abstract}
Innovation remains a complex concept that can't be analysed and researched by ignoring the definition and influences of all aspects and interactions which were identified in the innovation cycle. Consequently the paper initiate the development of a modern methodological framework to be applied for analysing business social innovations in its continuity to be used by companies to adapt their activities to the current market demands. These innovations are intended for running innovative company, with employees ready for new ideas.

The research development has taken into analyse several approaches: the concept of social innovation, the manner of which social innovation can be analysed, focusing on methodological aspects and the third part presents the conclusions.

Given the present economic crises effects, its societal and social consequences in a reduced interest for applied social innovation, people tend to choose not making changes in their life and work despite new and innovative ideas; this can be taken as an approach for to avoiding risks and activity disruptions. As results our expectations merge within the idea that a complex society requires complex answers at all problems and personalised applications of any new theory or idea. Therefore the purpose of the paper is to propose concrete ideas of social innovation that can be easily put into practice.
\end{abstract}

Keywords: virtual social innovation, social development

JEL Codes: O35, O2

\section{Introduction}

The interest in the development of social innovation is the result of the necessity to create a better quality of activities for people and communities. The current environment is in a process of 'rediscovering of social innovation' understanding them as a vehicle creating social change. (Phills, Deiglmeier and Miller, 2008, p. 34).

One of most important definitions from the social innovation literature is from Max Weber who defined the relationship between the social order and innovation by the impact on social change of behaviors initially considered to be abnormal. 


\author{
(online) $=$ ISSN $2285-3642$ \\ ISSN-L = $2285-3642$ \\ Journal of Economic Development, Environment and People \\ Volume 3, Issue 2, 2014 \\ URL: $\underline{\text { http://jedep.spiruharet.ro }}$ \\ e-mail: office jedep@spiruharet.ro
}

In the West, social innovation was more imposed in institutional field and, by extension, in economic and technological innovation field. (Matei, 2009)

For many years, developed countries are in a competition on innovation capacity and different ways of measuring it have been developed, but the capacity of innovation tends to refer only to the economic, technological and scientific field and not to social field.

Recently we are starting to see the importance given to the development of social innovation, supported to some extent by various programs.

An example of institutional development of social innovation is Great Britain which was one of the first states with a developed plan of policies supporting social innovation. (Matei, 2009)

In the existing literature there is still no precise definition of the term social innovation. To give a correct definition we start from the limited literature in this field to identify common elements and finally we create a synthetic formula, considering the fact that a successful social innovation should be culturally acceptable, economically sustainable and technologically feasible.

The aim of the article is to present the methodological framework for analysis of social innovation taking into account the changes that occur in today's society.

In the first part of the article the concept of social innovation is defined and explained, the second part presents an analysis of the concept shown with the methodological aspects, and the last part presents the conclusions.

\title{
2. Social innovation and its importance
}

To define social innovation it is necessary first to define the term of innovation. In the research literature there are different approaches to defining this concept.

One of the approaches propose to classify the concepts of innovations according to four dimensions (Carayannis, Gonzalez and Wetter, 2003):

The process of innovation (the way in which an innovation is developed, diffused and adopted);

The content of innovation (technical or social nature);

The context of innovation (the environment in which the innovation is emerges and is developed);

The impact of innovation (social or technological change that results from innovation).

In designing a clearer definition of social innovation, the major problem is related to low capacity in differentiating between some types of innovations (economic, organizational, technological, scientific, and social).

The natural language knows the general term of innovation, but its meaning is sanded for the particular cases of technical and scientific fields. The problem is that it produces a sense transfer from natural language to the new term of social innovation. This transfer was proved as an obstacle in the conceptualization of social innovation. (Zamfir, 2009)

Social innovation is about new ideas that work to address pressing unmet needs. We simply describe it as innovations that are both social in their ends and in their means. 


\author{
(online) = ISSN $2285-3642$ \\ ISSN-L = $2285-3642$ \\ Journal of Economic Development, Environment and People \\ Volume 3, Issue 2, 2014 \\ URL: $\underline{\text { http://jedep.spiruharet.ro }}$ \\ e-mail: office jedep@spiruharet.ro
}

Social innovations are new ideas (products, services and models) that simultaneously meet social needs (more effectively than alternatives) and create new social relationships or collaborations. (Murray, CalulierGrice and Mulgan, 2010)

The meaning can even go to the extend that social innovation responds to a social problem or social care, and for this it is known another definition that sais: "social innovation is a new solution to a social problem, solution that is more effective, efficient, sustainable and equitable than the existent solutions and for what the created value is increased primarily for society as a whole more than for private individuals." (Phills, Deiglmeier, 2008)

Social innovation should produce social, cultural, normative or regulatory change of society. (Heiskala, 2007) An innovation should introduce a substantial change in a particular field of activity.

To make a difference between economic innovation and social innovation, it is necessary to mention if the purpose of this innovation is to obtain or not a profit?

Even if the economic innovations produce an increase of well-being for individuals, quality of life, they are also created and distributed for profit. Most authors consider that the specific of social innovations consist in the fact that they are not created to obtain profit: social innovations consist in "innovative activities and services reasoned by order to meet a social need, run by organizations, companies or individuals whose main purpose is social and the profit is reinvested"; "it is different from innovation in business which are generally motivated by profit maximization and distributed by organizations that have profit primarily aimed". (Mulgan, 2006)

The social innovation is not produced in order to meet the needs of a specific individual or group or origin, but has an impact at the macro level. Social innovation creates value not only for direct consumer. (Leadbeater, 2008) For example, the fact that educational services have been improved by introducing new methods of organisation that have a long-term positive effect not only on students but on the entire community.
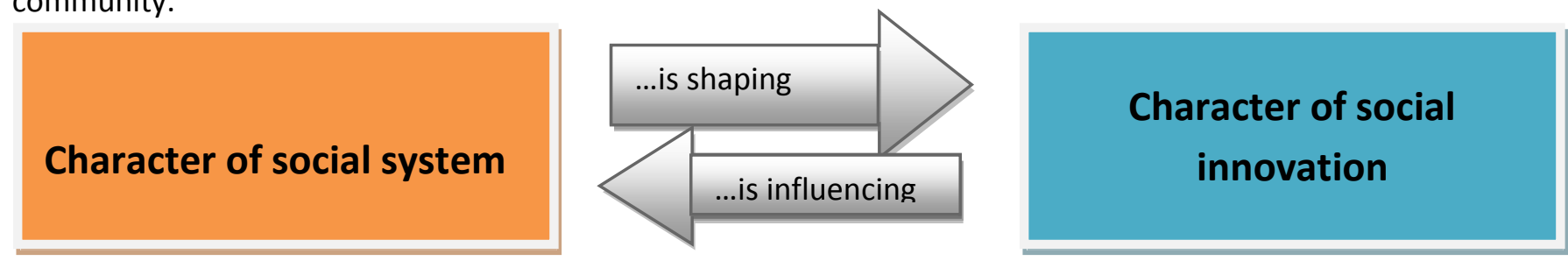

Fig. 1: Interrelation between social system and social innovation

As shown in the figure above, there is interdependence between the character of the social system and the character of social innovation.

It is essential to emphasize that the role of social innovations in community is two-fold: social innovations are shaped by social system (legal framework, actors involved in innovation development, etc.) and at the same time they are influencing the social system, as they have a purpose to change some aspects of the social system (Fig 1). 


\author{
(online) $=$ ISSN $2285-3642$ \\ ISSN-L = 2285 - 3642 \\ Journal of Economic Development, Environment and People \\ Volume 3, Issue 2, 2014 \\ URL: http://jedep.spiruharet.ro \\ e-mail: office jedep@spiruharet.ro
}

\title{
3. Analysis of innovation in Romania
}

Romania has a weak position in the European ranking on the production, assimilation and dissemination of innovation measured by European Innovation Scoreboard. In this context, addressing the topic of social innovation at academic level gains major importance.

Social innovation in Romania is facing major deficits of culture and supportive cultural, legislative, organizational and political deficits for this point of view. (fig. 2)

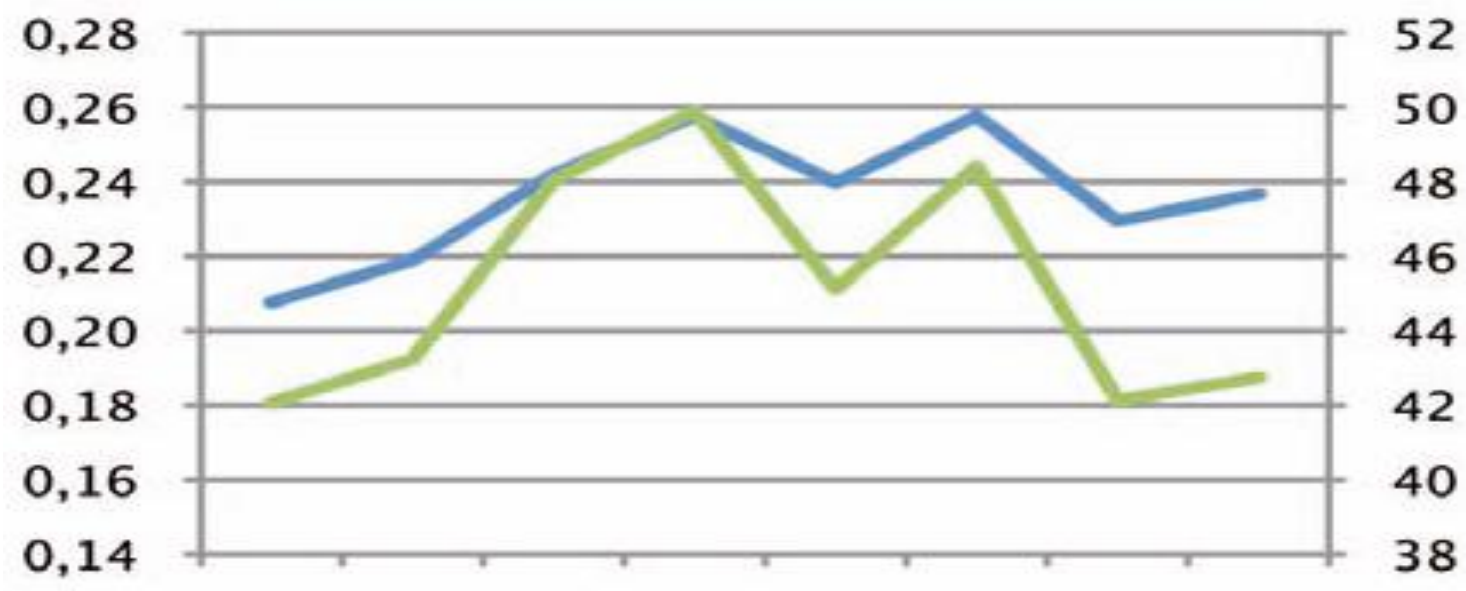

20062007200820092010201120122013

Innovation index

Relative to EU

Fig.2: Innovation performance of Romania comparative with EU

The graph shows that Romania is a modest innovator. Innovation performance increased up until 2009 and it has fluctuated ever since. Relative performance to the EU has worsened from being close to $50 \%$ in 2009 to $43 \%$ in 2013. Romania is performing well below the average of the EU for almost all indicators. (Innovation Union Scoreboard 2014)

\section{Conclusions}

The concept of social innovation is broad and difficult to define. We can understand social innovation by examining at the same time the other types of innovation. According to methodological research, social innovation is understood as a sum of new ideas, new knowledge or new projects used in an original manner.

Nowadays, we are being confronted with a special need to develop new methods of social innovation, and for that we have to use a plan to stimulate them. 


\author{
(online) $=$ ISSN $2285-3642$ \\ ISSN-L = 2285 - 3642 \\ Journal of Economic Development, Environment and People \\ Volume 3, Issue 2, 2014 \\ URL: http://jedep.spiruharet.ro \\ e-mail: office jedep@spiruharet.ro
}

\title{
5. References
}

[1] Carayannis, E., g., Gonzalez, E., Wetter, J. (2003). "The nature and dynamics of discontinuous and disruptive innovations from a learning and knowledge management perspective.", In Larisa V. Shavinina (Eds.), The International Handbook on Innovation - A Unique Compendium Bringing Together the Leading Scholars in the Field of Innovation. UK: Elsevier pp: 45

[2] Heiskala, R., Timo, J., (2007), Social innovations, institutional change and economic performance: making sense of structural adjustment processes in industrial sectors, regions and societies, Making Sense of Structural Adjustment Processes in Industrial Sectors, Regions and Societies Sitra's Publication, no. 281, the Finnish Innovation Fund, Cheltenham: Edward Elgar pp:264

[3] Leadbeater, C., (2008), Understanding Social Innovation, Center of Social Impact in Melboume, $16^{\text {th }}$ September, available at:

http://www.charlesleadbeater.net/cms/xstandard/Understanding\%20Social\%20Innovation.pdf

[4] Matei, A., (2009), "Inovatia sociala - o harta tematica", Inovatia sociala, no. 2, pp. 86

[5] Mulgan, G., (2006) The Process of Social Innovation in Innovations. Technology, Governance, Globalization, 2006, MIT Press, pp. 145-62

[6] Murray, R., Caulier-Grice, J., Mulgan, G., (2010). The Open Book of Social Innovation. London: Nesta pp:

[7] Phills, Jr., James, A., Deiglmeier, K., Miller D., T., (2008), Rediscovering Social Innovation in Stanford Social Innovation Review Fall 2008 pp:

[8] Zamfir, C. (2009), "Inovatia sociala: context si tematica", Inovatie sociala, no. 1, pp. 1

[9] "Innovation Union Scoreboard 2014" available at: http://ec.europa.eu/enterprise/policies/innovation/files/ius/ius-2014 en.pdf (accesed 4 April 2014) 